\title{
Strategi Kebijakan Peningkatan Daya Saing Rumput Laut Indonesia di Pasar Global
}

\author{
Riady Ibnu Khaldun* \\ riadyibnukhaldun@rocketmail.com
}

\begin{abstract}
Abstrak
Penelitian ini bertujuan untuk menganalisis strategi Pemerintah Indonesia dalam upaya meningkatkan daya saing produk rumput laut di pasar global. Jarak waktu yang digunakan dalam memberikan batasan waktu adalah 2009 hingga 2014. Pemerintah Indonesia menyadari besarnya potensi komoditas rumput laut sehingga perlu dimaksimalkan. Optimalisasi potensi tersebut dilakukan oleh pemerintah melalui skema kebijakan revitalisasi, industrialisasi, dan penerapan standarisasi rumput laut. Implementasi kebijakan yang diterapkan oleh pemerintah tersebut tidak dapat dioptimalisasikan karena timbulnya tantangan berupa perbedaan kepentingan dengan para pelaku usaha. Tantangan tersebut diantisipasi oleh pemerintah melalui strategi sinergitas kerjasama dengan aktor lain yang memiliki kepentingan berdasarkan Teori Developmental State, Konsep The Role of Government mendeskripsikan bahwa strategi yang diterapkan oleh Pemerintah Indonesia dalam upaya peningkatan daya saing produk rumput laut di pasar global dilakukan dengan mengeluarkan kebijakan yang memberikan kesempatan kepada peran aktor lainnya untuk berpartisipasi aktif dalam mengoptimalisasikan implementasi kebijakan.
\end{abstract}

Kata Kunci: Daya Saing, Industrialisasi, Revitalisasi, Standarisasi, Strategi Kebijakan

\begin{abstract}
This research aims to analyze the strategic policy of Indonesian Government towards increasing the competitiveness effort on seaweed products in global markets. The periods of this research started from 2009 to 2014 as the time intervals. Indonesian Government realized that seaweed commodities had great potentials that should be maximized. Revitalization, Industrialization, and Standardization are the policies that Indonesian Government established to optimize the seaweed potentials. The implementation of policies that applied by the government cannot be optimized because the existing of interest differentiation between government and private actor as a challenge. These challenges anticipated by the government through synergistic strategy with another actors who have an interest in seaweed commodities based on Theory Developmental State, The Role of Government concepts described the strategy that adopted by the Indonesian Government in an effort to increase the competitiveness of seaweed products in the global market is by issuing a policy that gives opportunity for the role of other actors to participate actively in optimizing the policy implementations.
\end{abstract}

Keywords: Competitiveness, Industrialization, Revitalization, Standardization, Strategic Policy

\section{Pendahuluan}

Globalisasi merupakan salah satu acuan utama dalam faktor perkembangan hubungan internasional. Setiap negara pada saat ini terpacu untuk melakukan interaksi satu sama lain dalam mencapai tujuan masing-masing negara

\footnotetext{
* Korespondensi: Program Studi Ilmu Pemerintahan, Jurusan Administrasi, Universitas Tadulako, Jl. Banteng Blok C1 No. 4 Palu-Sulawesi Tengah.
} 
dengan menciptakan sistem era dunia tanpa batas. Dalam konsep globalisasi terutama dalam sektor ekonomi pada saat ini yang terjadi adalah menipisnya batas-batas negara dalam beberapa kegiatan seperti halnya ekonomi atau pasar, secara nasional atau regional, yang sejalan dengan mengglobalnya aktor-aktor yang terlibat dalam proses kegiatan ekonomi tersebut. Salah satu dampak dalam sektor ekonomi yang mendapatkan pengaruh besar terhadap era globalisasi adalah rezim perdagangan internasional yang menciptakan pengurangan hambatan dalam perdagangan internasional, sehingga memperlancar arus perdagangan, investasi, mata uang, dan informasi (Winarno, 2009).

Globalisasi membuka peluang kepada setiap negara di seluruh dunia untuk dapat memasarkan dan menjual produknya ke pasar global. Hal tersebut menyebabkan setiap negara membangun strategi-strategi tertentu untuk dapat meraih keuntungan dalam sistem perdagangan internasional. Strategi dari masing-masing negara dikategorikan ke dalam kepentingan nasional (national interest) setiap negara. Kepentingan nasional adalah komposisi dari unsur-unsur kebutuhan negara yang menjadi tujuan fundamental dan faktor akhir, sehingga mengarahkan para pengambil keputusan dalam proses perumusan kebijakan suatu negara (Banyu dan Yanyan, 2005:35).

Setiap negara melakukan kompetisi satu sama lain untuk menguasai pangsa pasar dunia. Beberapa komoditas unggulan yang memiliki permintaan besar di pasar global menjadi kekuatan bagi masing-masing negara. Konsep absolute advantages menjadi salah satu acuan yang dapat menyatakan bahwa negara yang memiliki sumber daya yang besar ditambah inovasi akan memiliki keunggulan yang sangat besar dalam perdagangan global. Apabila suatu negara memiliki sumber daya yang besar terhadap salah satu sektor perdagangan maka negara tersebut memiliki satu keuntungan dalam perdagangan global. Beberapa jenis komoditas perdagangan yang menjadi sektor unggulan dalam perdagangan global adalah sektor pertambangan, pertanian, perkebunan, serta kelautan dan perikanan.

Kelautan dan Perikanan merupakan salah satu sektor yang paling penting di dunia karena tingginya angka kebutuhan terhadap produk kelautan dan perikanan sebagai sumber makanan, nutrisi, pendapatan, dan mata pencaharian dari ratusan juta manusia yang dibuktikan dengan konsumsi produk kelautan dan perikanan per kapita 
dunia pada Tahun 2013 mencapai $20 \mathrm{~kg}$ (Bappenas, 2014). Indonesia sebagai negara maritim memiliki potensi sumber daya kelautan dan perikanan yang sangat besar dengan besaran potensi mencapai 3000 triliun per tahun, akan tetapi yang sudah dimanfaatkan hanya sekitar 225 triliun atau sekitar 7,5\% saja terdiri dari komoditas unggulan yakni tuna, udang, cakalang, kerapu, dan rumput laut (Kementerian Kelautan dan Perikanan, 2016).

Di antara beberapa komoditas kelautan dan perikanan unggulan yang dimiliki oleh Indonesia tersebut rumput laut merupakan salah satu komoditas unggulan yang memiliki potensi yang sangat besar. Potensi Indonesia terhadap komoditas rumput laut didukung oleh luas laut sebesar 5.8 juta $\mathrm{km}^{2}$ dengan total luas area budidaya rumput laut mencapai 1.110 .900 ha (LIPI, 2009). Terdapat kurang lebih 555 jenis atau 45 persen jumlah spesies plasma nutfah ${ }^{\dagger}$ rumput laut di dunia berada di Indonesia. Berdasarkan data dari World Bank Report (2006) yang menyatakan bahwa komoditas perdagangan rumput laut memiliki peluang pasar yang besar dinilai berdasarkan peningkatan pertumbuhan permintaan rumput laut global sebesar 5-10\% setiap tahun yang menjadi salah satu acuan terhadap besarnya potensi komoditas rumput laut tersebut (Kementerian Kelautan dan Perikanan, 2014).

Sepuluh negara eksportir rumput laut terbesar di dunia adalah China, Indonesia, Jepang, Chile, Amerika Serikat, Korea Selatan, Perancis, Filipina, Irlandia, dan Peru. Di antara beberapa negara tersebut China, Indonesia, Filipina, Korea Selatan, dan Jepang merupakan negara produsen rumput laut terbesar di dunia. Berdasarkan data dari Bank Indonesia (2012), menyatakan bahwa Indonesia merupakan produsen terbesar kedua di dunia setelah China dan eksportir rumput laut terbesar di dunia. Pada tahun 2011 realisasi volume ekspor rumput laut Indonesia mencapai 159.075 ton, dibandingkan dengan realisasi Chile dan China masing-masing mencapai 67.768 ton dan 36.269 ton. Berdasarkan penguasaan pangsa pasar rumput laut global Indonesia hanya meraih 20\%, dibandingkan China sebesar 24\%, dan Chile sebesar 10\% (Lestari, 2013). Total realisasi volume ekspor rumput laut Indonesia tidak berbanding lurus dengan total realisasi nilai ekspor rumput laut Indonesia di pasar global. Realisasi nilai ekspor rumput laut Indonesia pada tahun 2011 hanya 
berkisar US\$157.586.549 dibandingkan dengan realisasi nilai ekspor rumput China di tahun yang sama mencapai US\$ 188.691.874, produk rumput laut Indonesia dianggap lemah dan memiliki nilai harga ekspor yang rendah. Nilai harga ekspor per Ton rumput laut Indonesia berada di urutan ke delapan dunia yang berkisar US\$10.000. Nilai harga ekspor per Ton rumput laut untuk negara Jepang, Amerika Serikat, China, dan Chile pada tahun 2011 mencapai masing-masing US\$174.000, US\$120.030, US\$ 52.000, dan US\$12.000, nilai harga ekspor per Ton rumput laut negara-negara tersebut jauh berada di atas Indonesia (Kementerian Kelautan dan Perikanan, 2014).

Rendahnya realisasi nilai ekspor rumput laut Indonesia di pasar global disebabkan oleh jenis produk ekspor rumput laut Indonesia yang didominasi oleh produk rumput laut kering (raw material) sebesar 80\% dan produk rumput laut olahan (Agar-agar dan Karaginan) sebesar 20\%. Tingginya peningkatan produksi budidaya rumput laut Indonesia setiap tahunnya tidak sejalan dengan peningkatan daya serap industri olahan rumput laut Indonesia yang hanya berjumlah 18 unit. Hal tersebut menyebabkan rendahnya daya serap produk rumput laut kering dalam negeri sehingga mengharuskan sebagian besar rumput laut kering di ekspor karena besarnya permintaan rumput laut kering di pasar global sebagai bahan baku industri (Kementerian Kelautan dan Perikanan, 2013).

Menyadari besarnya potensi peluang pasar rumput laut di pasar global Pemerintah Indonesia berinisiatif untuk melakukan upaya peningkatan daya saing rumput laut sebagai langkah untuk meningkatkan keuntungan dalam perdagangan rumput laut global dan peningkatan kesejahteraan masyarakat khususnya masyarakat pesisir. Upaya tersebut dilakukan Pemerintah Indonesia melalui peningkatan sektor hulu (budidaya) rumput laut sebagai langkah pemerintah dalam meningkatkan hasil dan kualitas produksi rumput laut, sektor hilir (industri) dengan melakukan industrialisasi rumput laut sebagai langkah peningkatan daya saing rumput laut berbasis upgrading dengan memberikan nilai tambah terhadap produk ekspor rumput laut Indonesia, dan penerapan standarisasi sebagai acuan utama dalam menjaga kualitas produk rumput laut.

Langkah tersebut dilakukan Pemerintah Indonesia sebagai public actor yang diwujudkan melalui beberapa kebijakan dalam meningkatkan daya saing rumput laut Indonesia di pasar global seperti program revitalisasi rumput laut nasional, 
hilirisasi atau industrialisasi rumput laut, dan penerapan standarisasi rumput laut. Akan tetapi, dalam implementasi kebijakan tersebut Pemerintah Indonesia mengalami kesulitan dalam menghadapi para pelaku usaha rumput laut sebagai private actor yang menjalankan dari sisi bisnis rumput laut. Hal tersebut menjadi tantangan utama dalam upaya peningkatan daya saing rumput laut Indonesia di pasar global. Sebagai pihak yang memiliki peran penting dalam menjalankan sisi bisnis sektor komoditas rumput laut para pelaku usaha rumput laut memiliki kepentingan tersendiri dalam komoditas rumput laut. Perbedaan kepentingan dari masing-masing pihak tersebut baik public actor dan private actor menjadi permasalahan utama dalam meningkatkan daya saing rumput laut Indonesia di pasar global.

Terdapat dua kepentingan yang berbeda di antara pemerintah dan para pelaku usaha rumput laut dalam komoditas rumput laut. Hal tersebut menjadi tantangan dalam upaya peningkatan daya saing produk rumput laut di pasar global sehingga dibutuhkan adanya sinergitas kerjasama di antara kedua belah pihak baik pemerintah dan para pelaku usaha rumput laut. Dengan terciptanya sinergitas kerjasama di antara kedua belah pihak tersebut upaya peningkatan daya saing rumput laut Indonesia di pasar global dapat dioptimalkan. Berdasarkan permasalahan tersebut, maka tulisan ini akan membahas mengenai strategi kebijakan Pemerintah Indonesia dalam meningkatkan daya saing produk rumput laut di pasar global.

\section{Kajian Pustaka}

Peningkatan perkembangan ekonomi didefinisikan baik dalam pertumbuhan, produktivitas, dan daya saing, merupakan the foremost dan single-minded state priority action (Johnson, 2004). Kebijakan pemerintah merupakan sebuah acuan dalam upaya peningkatan pertumbuhan ekonomi melalui peningkatan daya saing produk berdasarkan konsep daya saing. Demikian halnya dengan komoditas rumput laut Indonesia, untuk meningkatkan daya saing produk rumput laut di pasar global maka diperlukan beberapa strategi yang tepat untuk dapat mengoptimalisasi hal tersebut.

Kombinasi dari peranan Konsep Developmental State, Public Policy, dan The Role of Government adalah untuk menjabarkan dan menganalisis bentuk strategi kebijakan yang diterapkan oleh Pemerintah Indonesia dalam upaya untuk 
meningkatkan daya saing produk rumput laut di pasar global. Konsep Developmental State memiliki peranan dalam menjabarkan peran masing-masing aktor yang memiliki kepentingan dalam komoditas rumput laut dan juga untuk menganalisis bentuk strategi yang tepat bagi Pemerintah Indonesia dalam mengoptimalisasi implementasi kebijakan yang diterapkan. Konsep Public Policy untuk menekankan bahwa implementasi kebijakan bersifat menimbulkan dampak negatif berupa konflik terhadap aktor-aktor yang memiliki kepentingan di dalamnya sehingga dibutuhkan upaya untuk dapat meminimalisir dampak negatif di samping untuk memaksimalkan upaya pemerintah. Konsep The Role of Government adalah untuk menganalisis bentuk dan jenis strategi kebijakan yang diterapkan oleh Pemerintah Indonesia sebagai pemegang peranan penting dalam menentukan arah tujuan negara (National Interest).

Teori Developmental State merupakan konsep yang digunakan untuk menjelaskan dan menganalisis strategi Pemerintah Indonesia dalam upaya peningkatan daya saing produk rumput laut di pasar global terhadap tantangan yang dihadapi. Developmental State sebenarnya merupakan sebuah gagasan yang sama terhadap konsep Capitalist Developmental State akan tetapi diungkapkan dengan cara yang berbeda (Winanti, 2003:179). Pada dasarnya Developmental State adalah sebuah teori yang menggambarkan mengenai upaya industrialisasi di beberapa negara di Asia Timur sebagai langkah peningkatan pertumbuhan ekonomi (Bolesta, 2007:105).

\section{Gambar 1. The Developmental Actor Triangle}

\section{Government Actor}

Pemerintah

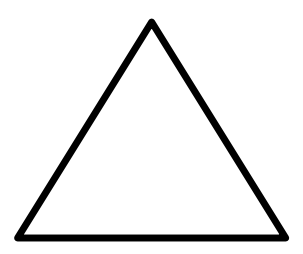

Society Actor

Lembaga Penelitian
Private Actor

Para Pelaku Usaha 
Teori Developmental State menekankan bahwa dalam upaya peningkatan daya saing produk rumput laut di pasar global terdapat tiga aktor yang memiliki peranan yang sangat penting untuk mengoptimalisasi implementasi kebijakan tersebut yaitu Pemerintah (Government Actor), Para Pelaku Usaha (Private Actor), dan Lembaga Penelitian (Society Actor). Ketiga aktor tersebut memiliki peranan masing-masing dalam upaya untuk memaksimalkan pencapaian terhadap implementasi kebijakan peningkatan daya saing produk rumput laut di pasar global, sehingga dibutuhkan adanya upaya kerjasama dalam bentuk sinergitas untuk dapat memaksimalkan implementasi kebijakan tersebut.

Permasalahan yang dihadapi oleh Indonesia dalam upaya peningkatan perkembangan ekonomi negara melalui peningkatan daya saing produk rumput laut adalah perbedaan kepentingan di antara pemerintah (government actor) dengan para pelaku usaha rumput laut (private actor) yakni kepentingan pemerintah terhadap kebijakan pengenaan pajak dan pelarangan ekspor bahan baku untuk merangsang peningkatan daya saing rumput laut melalui pengolahan bahan baku rumput laut melalui industri dalam negeri sebelum di ekspor, sedangkan para pelaku usaha rumput laut menganggap bahwa kapasitas konsumsi industri pengolahan rumput laut dalam negeri masih sangat terbatas sehingga menghambat penyerapan rumput laut nasional oleh pasar di tengah produksi rumput laut Indonesia yang melimpah (Asosiasi Rumput Laut Indonesia, 2014). Perbedaan kepentingan di antara kedua belah pihak tersebut menyebabkan timbulnya kesan tindakan yang bertolak belakang di antara pemerintah dengan para pelaku usaha rumput laut yang pada akhirnya menyebabkan tidak optimalnya hasil dari upaya tersebut.

Perbedaan kepentingan tersebut menjadi permasalahan sebagai tantangan dalam upaya peningkatan daya saing produk rumput laut di pasar global. Sehingga untuk menyelesaikan permasalahan tersebut dibutuhkan strategi berdasarkan teori Developmental State adalah perlu dilakukannya sinergitas dalam hal ini kerjasama di antara kedua belah pihak untuk menyiasati tantangan yang dihadapi. Sinergitas di antara kedua belah pihak baik pemerintah dan para pelaku usaha adalah untuk mengotimalisasikan upaya peningkatan daya saing produk rumput laut sebagai salah satu langkah peningkatan perkembangan ekonomi negara. Sinergitas kerjasama yang dapat dilakukan oleh kedua belah pihak adalah dengan saling bertukar informasi 
untuk dapat menyelesaikan permasalahan masing-masing dan menyatukan kepentingan untuk pencapaian tujuan bersama. Terdapat fundamental dalam karakteristik konsep Developmental State, yaitu (Johnson, 2004): 1) Dalam permasalahan pasar, negara dalam hal ini diwakili oleh pemerintah tidak melakukan penggantian kepemilikan secara langsung terhadap sektor swasta, akan tetapi pemerintah melakukan campur tangan melalui instruksi serta arahan berdasarkan strategi nasional; 2) Dibutuhkan hubungan kerja sama yang baik di antara pemerintah dan para pelaku usaha untuk mencapai satu tujuan yang sama menghindari kesan saling bertolak belakang dalam menyusun kebijakan. Apabila sinergitas di antara pemerintah dan para pelaku usaha akan mengakibatkan terwujudnya tujuan yang sama dalam melakukan implementasi kebijakan yakni pemerintah diberikan kesempatan untuk dapat melakukan manuver dalam mengambil beberapa langkah inisiatif terhadap berbagai macam kebijakan yang dianggap menguntungkan dan tetap memberikan kesempatan serta dukungan penuh kepada para pelaku usaha untuk dapat mengikuti kebijakan tersebut.

Teori Developmental State juga menggambarkan bahwa untuk mencapai keberhasilan dalam perkembangan ekonomi negara dibutuhkan kombinasi peran dari aktor utama yaitu pemerintah sebagai Public Actor, para pelaku usaha sebagai Private Actor, dan lembaga penelitian yang mewakili Society Actor dalam memberikan informasi tambahan terkait hasil penelitian sebagai data rujukan (Wilson, 2014). Untuk mencapai keberhasilan dalam upaya peningkatan daya saing produk rumput laut Indonesia di pasar global kedua aktor utama yaitu pemerintah dan para pelaku usaha rumput laut harus melakukan sinergitas kerjasama ditambah dengan lembaga penelitian sebagai Society Actor agar dapat membangun sebuah keputusan bersama yang nantinya dapat mendukung satu sama lain dalam mencapai keberhasilan dalam upaya peningkatan daya saing produk rumput laut Indonesia di pasar global.

Dalam Teori Public Policy menyatakan bahwa kebijakan yang dikeluarkan oleh pemerintah merupakan tindakan yang dinyatakan dan dilakukan atau tidak dilakukan oleh pemerintah yang dapat ditetapkan dalam peraturan perundangundangan atau dalam Policy Statement yang berbentuk pidato-pidato dan wacana yang diungkapkan pejabat politik dan pejabat pemerintah yang segera ditindaklanjuti dengan program-program dan tindakan pemerintah (Suwitri, 2008:9). Teori Public 
Policy merupakan konsep untuk menganalisa alasan pemerintah dalam mengeluarkan suatu kebijakan tertentu. Dalam upaya implementasi kebijakan yang dilakukan oleh pemerintah akan memberikan pengaruh terhadap dampak negatif berupa konflik terhadap aktor-aktor lainnya yang memiliki kepentingan apabila kebijakan dianggap bertolak belakang dengan situasi atau kondisi yang terjadi di lapangan.

Dalam upaya peningkatan daya saing produk rumput laut di pasar global, Pemerintah Indonesia memiliki peran yang sangat penting dalam upaya mengimplementasikan hal tersebut. Peran Pemerintah Indonesia sebagai Government Actor adalah pemegang kendali kebijakan untuk menentukan arah orientasi kebijakan negara. Pada dasarnya peran Pemerintah Indonesia dalam upaya peningkatan daya saing produk rumput laut dapat dianalisis berdasarkan Teori The Role of Government ke dalam tiga bentuk jenis upaya, seperti (Goldstein, 2008:94-104): 1) The role of support policies, peran Pemerintah Indonesia dalam mengeluarkan kebijakan dalam negeri (domestik) yang mendukung upaya peningkatan daya saing produk rumput laut di pasar global. Beberapa kebijakan yang dimaksud adalah kemudahan kepada para pelaku usaha rumput laut untuk mendapatkan akses informasi, bantuan keuangan, subsidi pajak, dan beberapa kebijakan lainnya; 2) The role of competition policies, peran Pemerintah Indonesia dalam mengeluarkan kebijakan yang memberikan dukungan penuh terhadap upaya peningkatan daya saing produk rumput laut Indonesia di pasar global melalui kebijakan yang mendukung pengembangan sektor industri domestik dengan memperhatikan porsi perkembangan sektor industri asing untuk pasar dalam negeri; 3) The role of international policies, peran Pemerintah Indonesia dalam memberikan pengaruh terhadap kebijakan internasional dalam mendukung pengembangan daya saing produk dalam negeri.

Perbedaan kepentingan yang muncul di antara aktor-aktor yang memiliki kepentingan dalam komoditas rumput laut baik pemerintah dan para pelaku usaha menyebabkan munculnya tantangan dalam optimalisasi kebijakan tersebut. Sehingga dibutuhkan adanya strategi kebijakan oleh pemerintah sebagai pemegang kendali kebijakan untuk memaksimalkan pencapaian hasil yang diterapkan melalui skema kerjasama dalam bantuk sinergitas. Strategi kebijakan yang diterapkan oleh pemerintah dapat dianalisis dengan menggunakan konsep The Role of Government untuk 
mengetahui bentuk jenis kebijakan tertentu yang diterapkan oleh pemerintah dalam dalam upaya peningkatan daya saing produk rumput laut di pasar global.

\section{Metode Penelitian}

Metode penelitian ini dilakukan dengan pendekatan kualitatif, yakni peneliti sebagai instrumen utama dalam melakukan pengumpulan serta pengolahan data memusatkan perhatian pada proses dan makna terhadap suatu peristiwa dalam penyelidikan (Creswell, 1994:145). Pada dasarnya penggunaan pendekatan kualitatif dalam penelitian ini dimaksudkan karena menganggap pendekatan kuantitatif kurang dapat mewakilkan, apabila dilihat dari kurangnya jumlah indikator variabel untuk menjawab permasalahan dalam penelitian ini. Selanjutnya, proses analisis dilakukan secara deskriptif dengan menganalisis dan menyajikan fakta-fakta dalam melakukan pengaturan penulisan secara sistematis, sehingga hasil penelitian tersebut dapat dipahami dengan mudah.

Adapun metode pengumpulan data yang digunakan dalam penelitian ini adalah studi pustaka seperti melakukan kajian terhadap dokumen, laporan, dan artikel. Data primer yang akan digunakan dalam penelitian ini adalah berupa dokumen resmi yang dikeluarkan oleh Pemerintah Indonesia melalui lembagalembaga yang terkait seperti Kementerian Kelautan dan Perikanan, Kementerian Perindustrian, Kementerian Perdagangan dan Bank Indonesia, serta organisasi yang terkait seperti Asosiasi Rumput Laut Indonesia (ARLI), dan Komisi Rumput Laut Indonesia (KRLI). Data sekunder yang akan digunakan dalam penelitian ini adalah jurnal, artikel, dan berita yang dikeluarkan dari beberapa surat kabar atau hasil penelitian yang resmi.

\section{Hasil dan Pembahasan}

\section{Aktor-Aktor dalam Peningkatan Daya Saing Rumput Laut}

Pengembangan sektor komoditas rumput laut dalam rangka peningkatan daya saing rumput laut nasional dibebankan kepada seluruh aktor-aktor yang berkepentingan dalam komoditas rumput laut tersebut. Masing-masing kementerian dan instansi yang berada di bawah Pemerintah Indonesia seharusnya memiliki setiap kebijakan yang disusun berdasarkan fungsi dan tugas masing-masing. Akan tetapi, 
pada kenyataannya dalam struktur kebijakan dalam Pemerintah Indonesia tidak terjadinya sinergitas sehingga dianggap menyebabkan terjadinya overlapping policy. Masing-masing dari kementerian tersebut mengeluarkan kebijakan yang saling tumpang tindih.

Pemerintah Indonesia dalam upaya meningkatkan daya saing rumput laut di pasar global melalui kementerian-kementerian yang terkait harus membentuk skema kebijakan terhadap masing-masing kementerian. Berdasarkan fungsi dan tugas dari masing-masing kementerian akan memberikan gambaran serta alur yang jelas dalam proses implementasi kebijakan nantinya dan tidak bertolak belakang satu sama lain. Kebijakan yang dikeluarkan oleh pemerintah merupakan kebijakan yang diterapkan oleh masing-masing instansi kementerian berdasarkan fungsi dan tugas masing-masing untuk memberikan gambaran yang jelas terhadap suatu kebijakan yang akan diterapkan oleh pemerintah (Subarsono, 2005:2).

Berdasarkan fungsi dan tugas dari masing-masing kementerian yang bertanggung jawab dalam pelaksanaan peningkatan daya saing rumput laut setiap kementerian diharuskan berada dalam posisi masing-masing berdasarkan kewenangan yang telah ditugaskan. Kewenangan tersebut dapat berupa kementerian dan instansi lainnya dijadikan pendukung dalam hal menciptakan produk rumput laut Indonesia yang berdaya saing dan para pelaku usaha rumput laut (private actor) memiliki tugas untuk membantu peningkatan daya saing rumput laut nasional dari sisi bisnis dalam memberikan masukan dan informasi untuk menciptakan satu visi, misi, dan tujuan dalam peningkatan daya saing rumput laut nasional di pasar global.

\section{a. Pemerintah Indonesia}

Secara umum pemerintah merupakan pemegang kendali dalam mengatur pelaksanaan kebijakan. Pemerintah Indonesia sebagai government actor memiliki peran utama dalam melakukan upaya peningkatan daya saing produk rumput laut nasional melalui penetapan kebijakan terhadap ke mana arah dan tujuan komoditas rumput laut Indonesia. Kebijakan terhadap apa yang dikeluarkan oleh Pemerintah Indonesia terhadap komoditas rumput laut nasional akan memberikan pengaruh yang cukup besar terhadap seluruh aktor-aktor yang berkepentingan di dalamnya. 
Ketika pemerintah mengeluarkan suatu kebijakan, maka secara langsung pemerintah akan mendapatkan respon dari pihak yang memiliki kepentingan di dalamnya. Sehingga kebijakan yang dikeluarkan oleh pemerintah memiliki kekuatan yang besar dalam mempengaruhi arah dan tujuan negara berdasarkan strategi nasional. Dalam struktur dan fungsi kepemerintahan masing-masing kementerian memiliki peran masing-masing dalam upaya peningkatan daya saing produk rumput laut Indonesia di pasar global.

\section{b. Kementerian Kelautan dan Perikanan}

Sebagai instansi kepemerintahan yang memiliki peranan langsung terhadap sektor kelautan dan perikanan, Kementerian Kelautan dan Perikanan memiliki peran sebagai perumusan, penetapan, dan pelaksanaan kebijakan di bidang kelautan dan perikanan. Seluruh bidang yang berkaitan dengan kelautan dan perikanan baik pengelolaan barang milik atau kekayaan negara yang menjadi tanggung jawab Kementerian Kelautan dan Perikanan.

Berdasarkan konsep Blue Economy, peranan utama Kementerian Kelautan dan Perikanan dalam sumber daya kelautan dan perikanan adalah melakukan pengembangan berbagai inovasi yang berorientasi pada pelestarian sumber daya kelautan dan perikanan untuk memberikan manfaat secara ekonomi, sosial, dan lingkungan secara berkelanjutan. Menciptakan daya saing yang lebih tinggi melalui inovasi dan efisiensi yang berkelanjutan, melakukan pembangunan tanpa merusak lingkungan, menciptakan berbagai industri baru di bidang kelautan dan perikanan, serta menciptakan lapangan kerja baru melalui pemanfaatan sektor kelautan dan perikanan (Kementerian Kelautan dan Perikanan, 2014).

Secara khusus terkait dengan peningkatan daya saing rumput laut nasional Kementerian Kelautan dan Perikanan melalui Direktorat Jenderal Perikanan Budidaya mengeluarkan kebijakan melalui Peraturan Menteri Kelautan dan Perikanan Republik Indonesia Nomor Per.39/MEN/2011 tentang Organisasi dan Tata Kerja Loka Penelitian dan Pengembangan Budidaya Rumput Laut, Peraturan Menteri Kelautan dan Perikanan Republik Indonesia Nomor 7/PERMEN-KP/2013 tentang Sertifikat Asal Rumput Laut, dan Peraturan Menteri Kelautan dan Perikanan 
Republik Indonesia Nomor Per.27/Men/2012 tentang Pedoman Umum Industrialisasi Kelautan dan Perikanan.

Ketiga kebijakan yang dikeluarkan oleh Kementerian Kelautan dan Perikanan terkait upaya peningkatan daya saing rumput laut adalah wujud upaya Pemerintah Indonesia dalam melakukan upaya peningkatan daya saing rumput laut Indonesia di pasar global. Kebijakan tersebut dikeluarkan dalam rangka meningkatkan kualitas produksi rumput laut nasional dan pengenaan sertifikat asal rumput laut dalam rangka penyesuaian aturan yang diberlakukan dalam pasar global terutama ketentuan dari negara-negara pengimpor. Pedoman Umum Industrialisasi Kelautan dan Perikanan sebagai wujud peningkatan nilai tambah (upgrading) dan daya saing produk rumput laut di pasar global.

\section{c. Kementerian Keuangan}

Peran Pemerintah Indonesia melalui Kementerian Kuangan adalah melalui kebijakan fiskal yang merujuk kepada kebijakan yang dibuat pemerintah untuk mengarahkan ekonomi suatu negara melalui pengeluaran dan pendapatan pemerintah. Salah satu tujuannya adalah dengan memberikan bantuan kepada sektor komoditas rumput laut dalam rangka memberikan bantuan keuangan (finance) baik berupa pengaturan suku bunga pinjaman bagi para pelaku usaha rumput laut atau pemberian keringanan pajak bagi industri rumput laut, sebagai wujud upaya dukungan Pemerintah Indonesia dalam meningkatkan daya saing rumput laut nasional (Asosiasi Rumput Laut Indonesia, 2014).

\section{d. Kementerian Perindustrian}

Peran Kementerian Perindustrian dalam peningkatan daya saing rumput laut nasional adalah dengan melakukan pengembangan industri rumput laut Indonesia. Merujuk kepada Undang-Undang Nomor 3 Tahun 2014 tentang Perindustrian, Kementerian Perindustrian diberikan kepercayaan sebagai pemegang amanat Pasal 8 ayat 1 untuk mengatur permasalahan mengenai Rencana Perindustrian Induk Pembangunan Industri Nasional (RIPIN).

Menyadari bahwa potensi bahan baku rumput laut yang cukup besar, Pemerintah Indonesia melalui UU No. 3 Tahun 2014 mengenai RIPIN menyatakan 
bahwa industri rumput laut akan menjadi salah satu prioritas yang menjadi andalan masa depan bersama kelompok industri pangan bersama industri pengawetan dan pengolahan hasil laut, industri pengolahan susu, industri pengolahan buah-buahan dan sayuran, industri minuman, industri tepung serta industri gula berbasis tebu (Kementerian Perindustrian, 2014). Kebijakan tersebut dikeluarkan sebagai wujud upaya Pemerintah Indonesia dalam upaya meningkatkan daya saing produk rumput laut Indonesia di pasar global melalui mekanisme industrialisasi rumput laut oleh Kementerian Perindustrian.

\section{e. Kementerian Perdagangan}

Peran utama Kementerian Perdagangan terkait dengan upaya peningkatan daya saing produk rumput laut Indonesia di pasar global adalah dengan mengeluarkan dan mengatur kebijakan terkait permasalahan kebijakan ekspor dan impor produk rumput laut. Pemasaran produk rumput laut Indonesia di pasar global merupakan tanggung jawab dan fungsi utama dari Kementerian Perdagangan.

Untuk meraih hasil maksimal dalam penerapan kebijakan Pemerintah Indonesia dalam peningkatan daya saing produk rumput laut Indonesia di pasar global, Kementerian Perdagangan memegang kendali terhadap sisi pemasaran dan kebijakan terkait impor dan ekspor rumput laut. Trade Diplomacy merupakan pedoman utama Kementerian Perdagangan dalam membuka akses pasar bagi produk rumput laut Indonesia di pasar global. Kementerian Perdagangan memiliki peran dalam mengatur seluruh permasalahan terkait perdagangan produk rumput laut Indonesia.

\section{f. Kementerian dan Instansi Pendukung}

Beberapa kementerian dan instansi pendukung dalam upaya peningkatan daya saing rumput laut Indonesia di pasar global adalah Kementerian Koperasi Usaha Kecil dan Menengah, Kementerian Pembangunan Daerah Tertinggal, dan Badan Koordinasi Penanaman Modal. Pemerintah Indonesia melalui beberapa kementerian dan instansi terkait telah melakukan kerjasama yang ditandatangani dalam kesepakatan bersama lima kementerian dan satu lembaga.

Momerandum of Understanding (MoU) tentang Sinergitas Pengembangan Rumput Laut dalam Rangka Percepatan Pembangunan Ekonomi Masyarakat Daerah 
Tertinggal di Tujuh Provinsi disepakati bersama oleh Kementerian Kelautan dan Perikanan, Kementerian Perdagangan, Kementerian Perindustrian, Kementerian Pembangunan Daerah Tertinggal, Kementerian Koperasi Usaha Kecil dan Menengah, dan Badan Koordinasi Penanaman Modal. Bank Indonesia juga merupakan salah satu instansi atau lembaga terkait yang memiliki peran dalam pengembangan daya saing produk rumput laut Indonesia yang memiliki peran dalam sektor keuangan (finance). Badan Standarisasi Nasional (BSN) yang juga merupakan instansi lembaga Pemerintah Indonesia yang memiliki tanggung jawab dalam penyusunan standar nasional produk rumput laut Indonesia.

\section{g. Pelaku Usaha Rumput Laut}

Peran paling penting selain pemerintah (public actor) dalam upaya peningkatan daya saing adalah para pelaku usaha rumput laut (private actor). Mulai dari sektor hulu (budidaya) hingga hilir (industri) para pelaku usaha rumput laut mendapatkan pengaruh yang besar terhadap kebijakan yang dikeluarkan oleh pemerintah. Dalam kebijakan yang dikeluarkan oleh Pemerintah Indonesia terkait kebijakan peningkatan daya saing produk rumput laut Indonesia di pasar global, kepentingan yang paling besar dipengaruhi adalah kepentingan-kepentingan yang diwakili oleh para pelaku usaha rumput laut. Kebijakan yang dikeluarkan pemerintah terkait dengan upaya peningkatan daya saing rumput laut Indonesia di pasar global akan memberikan pengaruh kepada para pelaku usaha rumput laut sebagai aktor yang menjalankan sistem dari sisi bisnis dan pemerintah dari sisi birokrasi.

\section{h. Asosiasi Rumput Laut Indonesia}

Pelaku usaha rumput laut memiliki peran penting dalam upaya peningkatan daya saing ekspor rumput laut Indonesia di pasar global. Asosiasi Rumput Laut Indonesia (ARLI) memiliki peran sebagai wadah utama dari seluruh para pelaku usaha rumput laut Indonesia dari sektor hulu hingga hilir. ARLI memiliki salah satu tanggung jawab sebagai penampung aspirasi dari seluruh para pelaku usaha rumput laut terkait dengan seluruh aktivitas rumput laut dari budidaya, pengembangan, hingga aktivitas perdagangan. 
Aktivitas rumput laut Indonesia dari segi bisnis atau private diberikan kewenangan serta tanggung jawab penuh kepada ARLI. Dibentuk sebagai wadah bagi seluruh para pelaku usaha rumput laut Indonesia sehingga menjadikan ARLI sebagai salah satu aktor penting dalam upaya peningkatan daya saing rumput laut Indonesia di pasar global. ARLI mengakomodir seluruh kegiatan rumput laut nasional sebagai private actor termasuk aktivitas yang berhubungan langsung dengan pemerintah.

\section{i. Asosiasi Industri Rumput Laut Indonesia}

Asosiasi Industri Rumput Laut Indonesia (ASTRULI) adalah private actor lain dari sisi industri rumput laut Indonesia dalam upaya peningkatan daya saing rumput laut Indonesia di pasar global. Tujuan pembentukan ASTRULI adalah untuk mengakomodir seluruh aktivitas yang terkait dengan industri rumput laut nasional. Selain itu pembentukan ASTRULI memiliki dasar sebagai sinergi terhadap seluruh kepentingan stakeholders' rumput laut. Asosiasi Industri Rumput Laut Indonesia merupakan lembaga kerjasama antar pelaku industri dalam melakukan kerjasama dengan unsur pemerintah (Kementerian Perindustrian, 2014).

\section{j. Lembaga Penelitian}

Society Actor memiliki peran dalam mengontrol, memberikan masukan, dan informasi tambahan kepada pemerintah dan para pelaku usaha rumput laut untuk membantu dalam melakukan peningkatan baik dalam pemutuan dan penerapan kebijakan maupun dalam peningkatan sisi budidaya dan bisnis rumput laut. Society Actor dapat dikategorikan sebagai penengah di antara kedua aktor utama lainnya yaitu Government Actor dan Private Actor yang juga bisa ikut berpartisipasi dalam memberikan dukungan kepada dua aktor tersebut. Society Actor dapat dikategorikan sebagai lembaga penelitian atau Perguruan Tinggi yang bisa memberikan bantuan baik kepada pemerintah atau para pelaku usaha rumput laut (Wilson, 2014).

\section{k. Komisi Rumput Laut Indonesia}

Berdasarkan Peraturan Menteri Kelautan dan Perikanan Nomor Kep.26/MEN/2006 Mengenai pembentukan Komisi Rumput Laut Indonesia (KRLI) yang tujuannya untuk mengkoordinasikan dan mengintegrasikan seluruh 
unsur yang terkait di bidang usaha rumput laut di Indonesia, baik pemerintah maupun swasta sehingga menjadi usaha yang komprehensif, kompetitif, handal dan berkelanjutan serta menunjang revitalisasi perikanan. Struktur keanggotaan KRLI terdiri dari peneliti (researcher), pemerintah, dan para pelaku usaha rumput laut. Salah satu tujuan dari KRLI adalah untuk melakukan analisis dan penelitian terkait komoditas rumput laut yang hasilnya digunakan untuk pengembangan terkait dengan komoditas rumput laut tersebut.

\section{Perguruan Tinggi}

Sebagai penyedia informasi dan hasil penelitian Perguruan Tinggi memiliki peran penting dalam mengontrol dan memberikan masukan terhadap kebijakan yang dikeluarkan dan diterapkan oleh pemerintah. Untuk para pelaku usaha rumput laut, peran Perguruan Tinggi sangatlah penting dalam memberikan informasi dan pengetahuan terhadap pengembangan komoditas rumput laut baik dari segi budidaya (hulu) maupun segi industri (hilir). Sehingga hasil penelitian dari Perguruan Tinggi sangat penting terhadap perkembangan komoditas rumput laut baik bagi Government Actor atau Private Actor.

\section{Peran Para Aktor}

Developmental State merupakan konsep peningkatan perkembangan ekonomi negara yang diterapkan di negara-negara yang berada di kawasan Asia Timur. Integritas perpaduan unsur pemerintah negara (Government Actor) dan swasta (Private Actor) secara umum dilakukan untuk menciptakan pengembangan ekonomi negara. Intervensi pemerintah terhadap sektor pasar yang dibatasi dapat menciptakan perpaduan seimbang dalam peningkatan daya saing produk nasional. Demikian halnya dengan upaya pemerintah dalam peningkatan daya saing produk rumput laut Indonesia di pasar global. Peran pemerintah dan para pelaku usaha rumput laut yang disinergikan satu sama lain dapat menghasilkan upaya positif dalam rangka peningkatan daya saing produk rumput laut di pasar global.

Dalam beberapa karakteristik konsep Developmental State tentang peran negara dan pihak swasta menyatakan bahwa dalam permasalahan pasar, negara melakukan intervensi pasar hanya dengan melalui instruksi dan arahan berdasarkan 
strategi nasional. Dibutuhkan hubungan kerja sama yang baik di antara pemerintah dan para pelaku usaha untuk mencapai satu tujuan yang sama menghindari kesan saling bertolak belakang dalam menyusun kebijakan untuk mewujudkan tujuan yang sama dalam melakukan implementasi kebijakan. Disatu sisi, pemerintah diberikan kesempatan untuk dapat melakukan manuver dalam mengambil beberapa langkah inisiatif terhadap berbagai macam kebijakan yang dianggap menguntungkan, di sisi lainnya tetap memberikan kesempatan serta dukungan penuh kepada para pelaku usaha rumput laut.

Upaya yang terus dilakukan pemerintah dan para pelaku usaha rumput laut dalam rangka peningkatan daya saing rumput laut Indonesia di pasar global adalah dengan bekerja sama dalam mendukung satu sama lain. Pemerintah Indonesia giat melakukan sosialisasi kebijakan dan tata aturan pengembangan peningkatan daya saing rumput laut. Para pelaku usaha rumput laut senantiasa memberikan informasi kepada pemerintah terkait dengan isu yang dihadapi oleh komoditas rumput laut Indonesia.

Beberapa patokan dalam keberhasilan peran kedua pihak tersebut adalah dengan diselenggarakannya International Seaweed Symposium di Bali, Indonesia, pada tanggal 21-26 April, 2013. International Seaweed Symposium merupakan forum rumput laut terbesar di dunia di mana seluruh para pelaku usaha rumput laut dunia dan pemerintah dunia hadir dalam forum tersebut untuk membahas mengenai semua hal terkait dengan rumput laut. Forum tersebut mempertemukan para pelaku usaha dan pemerintah negara yang memiliki kepentingan dalam komoditas rumput laut dengan pemerintah dan para pelaku usaha rumput laut nasional. Dengan diselenggarakannya International Seaweed Symposium di Bali, Indonesia, maka pemerintah dan para pelaku usaha rumput laut nasional memiliki kesempatan besar untuk dapat mengembangkan daya saing rumput laut Indonesia di pasar global dan membuka kesempatan besar bagi produk rumput laut Indonesia (Asosiasi Rumput Laut Indonesia, 2014).

Peran kedua pihak tersebut dalam upaya peningkatan daya saing rumput laut Indonesia di pasar global adalah dengan diselenggarakannya Musyawarah Nasional III Asosiasi Rumput Laut Indonesia (ARLI), di Makassar, pada tanggal 8-10 Oktober 2014. Acara tersebut berhasil mempertemukan pemerintah dengan para pelaku usaha rumput laut, pemerintah dalam acara tersebut melakukan sosialisasi 
secara langsung kepada para pelaku usaha rumput laut terkait dengan upaya peningkatan daya saing rumput laut Indonesia di pasar global melalui tiga langkah utama yaitu melalui revitalisasi rumput laut nasional, industrialisasi rumput laut nasional, dan penerapan standarisasi rumput laut berdasarkan Standar Nasional Indonesia (SNI). Kedua belah pihak berhasil melakukan kerjasama yang diawali dengan sosialisasi oleh pihak pemerintah kepada para pelaku usaha rumput laut dan pertukaran informasi yang dilakukan oleh para pelaku usaha rumput laut kepada pemerintah.

Dengan dibentuknya Asosiasi Industri Rumput Laut Indonesia (ASTRULI) oleh Kementerian Perindustrian sebagai langkah penuh pemerintah dalam mendukung upaya peningkatan daya saing rumput laut Indonesia di pasar global. Melalui ASTRULI pemerintah mengharapkan adanya pertukaran informasi yang semakin bertambah guna membantu Pemerintah Indonesia dalam upaya memberikan dukungan penuh kepada pelaku usaha rumput laut Indonesia dalam meningkatkan daya saing rumput laut Indonesia di pasar global.

\section{Sinergitas Peran Para Aktor}

Kerja sama di antara kedua belah pihak yakni pemerintah dan para pelaku usaha rumput laut merupakan hal yang paling penting dalam mencapai keberhasilan dalam peningkatan perkembangan ekonomi khususnya terhadap upaya peningkatan daya saing ekspor rumput laut di pasar global untuk meningkatkan nilai harga ekspor per Ton rumput laut Indonesia. Teori Developmental State menggambarkan bahwa dalam upaya peningkatan daya saing terkait untuk menyiasati tantangan yang dihadapi oleh Pemerintah Indonesia maka diperlukan adanya upaya kerjasama dalam bentuk sinergitas. Seluruh aspek dan bentuk kebijakan yang diterapkan oleh Pemerintah Indonesia baik yang tertulis ataupun tidak tertulis akan tetapi disampaikan dan kemudian diimplementasikan termasuk ke dalam kebijakan pemerintah dalam upaya peningkatan daya saing rumput laut di pasar global.

Hal yang paling mendasar dalam penerapan kebijakan peningkatan daya saing rumput laut oleh Pemerintah Indonesia adalah agar para pelaku usaha dapat mengoptimalkan implementasi kebijakan tersebut dengan melakukan kerjasama. Adapun bentuk kerjasama yang dapat dilakukan oleh kedua belah pihak dilaksanakan 
dengan (1) melakukan pertukaran informasi mengenai permasalahan yang dihadapi, (2) mengikutsertakan para pelaku usaha rumput laut dalam menyusun kebijakan oleh pemerintah, (3) secara bersama-sama aktif dalam mengontrol dan menjaga kestabilan ekonomi khususnya peningkatan daya saing produk rumput laut di pasar global sehingga berdasarkan jenis strategi yang ditetapkan oleh Pemerintah Indonesia termasuk ke dalam konsep The Role of Support Policies.

Beberapa hal yang perlu diperhatikan oleh Pemerintah Indonesia dalam menciptakan birokrasi yang baik adalah dengan mengurangi sistem kerja birokrasi yang buruk sehingga kebijakan akan bersifat mendukung secara penuh terhadap strategi nasional yang dibangun. Pada dasarnya para pelaku usaha rumput laut memiliki kepentingan yang berseberangan dengan pemerintah dikarenakan adanya kesempatan berupa keuntungan yang lebih besar dalam bisnis rumput laut. Akan tetapi, tidak dapat dipungkiri bahwa sebenarnya upaya pemerintah dalam melakukan upaya peningkatan daya saing merupakan hal yang positif dalam peningkatan perkembangan ekonomi nasional. Para pelaku usaha rumput laut membutuhkan dukungan yang penuh apabila pemerintah ingin mengeluarkan suatu kebijakan, sehingga optimalisasi terhadap implementasi kebijakan oleh para pelaku usaha rumput laut dapat dimaksimalkan. Para pelaku usaha rumput laut membutuhkan dukungan yang besar baik berupa kebijakan yang dianggap dapat membantu secara penuh terhadap pelaksanaan kebijakan.

Dalam Teori Developmental State menyatakan bahwa para pelaku usaha membutuhkan positive role of government untuk bisa menghasilkan positive advantages (Bolesta, 2007:105). Sosialisasi merupakan salah satu cara atau strategi pemerintah kepada para pelaku usaha rumput laut agar dapat meningkatkan kesadaran dan pengetahuan untuk dapat menciptakan kesepakatan dalam suatu implementasi kebijakan. Dengan dipahami secara menyeluruh oleh para pelaku usaha rumput laut upaya pemerintah dalam meningkatkan daya saing rumput laut di pasar global dapat dioptimalkan guna mencapai hasil yang maksimal.

Membangun forum-forum bersama dan membangun beberapa kesepakatan bersama di antara kedua belah pihak oleh pemerintah telah merupakan sebuah strategi yang baik. Akan tetapi, permasalahan tersebut dapat diminimalisir atau disiasati dengan upaya kerjasama dalam bentuk sinergitas di antara kedua belah 
pihak baik pemerintah dan para pelaku usaha rumput laut. Sehingga optimalisasi kebijakan akan selaras dan pencapaian hasil akan berlaku maksimal dalam meningkatkan daya saing produk rumput laut Indonesia di pasar global.

\section{a. Sinergitas dalam Upaya Revitalisasi Sektor Hulu}

Untuk meningkatkan hasil nilai mutu dan produktivitas rumput laut Pemerintah Indonesia melakukan upaya revitalisasi sektor hulu karena sektor budidaya dianggap sebagai dasar utama dalam melakukan pengembangan hasil produksi budidaya rumput laut (raw material) untuk menunjang perkembangan ekonomi nasional khususnya untuk sektor kelautan dan perikanan secara menyeluruh dan berkesinambungan. Pengembangan sektor hulu dianggap penting untuk dapat meningkatkan perkembangan sektor hilir karena terdapat kesinambungan apabila sektor hulu dapat dioptimalkan dan ditingkatkan maka sektor hilir akan memberikan peningkatan hasil itu sendiri sebagai acuan terhadap bahan baku industri yang berkualitas tinggi.

Sinergitas kebijakan yang dilakukan oleh kedua belah pihak dalam hal ini pemerintah (government actor) dan para pelaku usaha rumput laut (private actor) adalah dengan melakukan sosialisasi terhadap penerapan kebijakan yang dilakukan oleh pemerintah melalui Kementerian Kelautan dan Perikanan kepada para pelaku usaha rumput laut (khususnya pembudidaya) terkait bagaimana mengambil tindakan dalam memproduksi rumput laut yang memiliki kualitas tinggi pada Musyawarah Nasional Asosiasi Rumput Laut Indonesia (ARLI) pada tanggal 08 Oktober 2014, di Makassar. Pemerintah memberikan beberapa gambaran terkait dengan implementasi kebijakan untuk dapat secara langsung disosialisasikan kepada seluruh para pelaku usaha rumput laut yang kemudian dilanjutkan dengan pertukaran berbagai bentuk informasi terkait dengan kendala dalam upaya peningkatan revitalisasi oleh para pelaku usaha rumput laut kepada pemerintah. Pemerintah juga melakukan upaya perumusan kebijakan terkait rencana zonasi wilayah pengembangan potensial rumput laut bersama dengan para pelaku usaha rumput laut untuk menghindari ancaman terkait dengan degradasi lahan budidaya rumput laut (Kementerian Kelautan dan Perikanan, 2014). 
Kebijakan yang dilakukan oleh Pemerintah Indonesia dalam rangka revitalisasi rumput laut adalah dengan memberikan penerapan standar teknologi budidaya dan standar mutu nasional rumput laut. Pemerintah Indonesia melakukan sosialisasi sebagai langkah sinergitas kepada para pelaku usaha rumput laut khususnya yang berperan di sektor hulu (budidaya) dan dengan memberikan pembinaan secara langsung kepada pelaku usaha rumput laut serta membangun tanggung jawab sadar berupa pengenalan "Mutu" pada pembudidaya maupun pelaku usaha lain agar terbangunnya kesadaran terhadap pentingnya standar mutu dan keamanan pangan (Asosiasi Rumput Laut Indonesia, 2014).

\section{b. Sinergitas dalam Upaya Industrialisasi Sektor Hilir}

Upaya yang dilakukan oleh Pemerintah Indonesia dalam melakukan sinergitas dengan para pelaku usaha rumput laut Indonesia terhadap program industrialisasi sektor hilir rumput laut adalah dengan melakukan serangkaian koordinasi dengan para pelaku usaha rumput laut yang dikoordinasi oleh Asosiasi Rumput Laut Indonesia (ARLI) dengan menyelenggarakan International Seaweed Symposium ke 21 di Bali, Indonesia, pada tanggal 21 April 2013. International Seaweed Symposium (ISS) merupakan acara dengan tema rumput laut berskala internasional yang tujuan pengadaan acara tersebut khususnya di Indonesia adalah untuk memperkenalkan kepada dunia dan pasar global mengenai potensi rumput laut yang dimiliki oleh Indonesia. Selain untuk mempertemukan para pelaku usaha rumput laut nasional (stakeholders) dengan para pelaku usaha rumput laut global, acara tersebut juga merupakan ajang sosialisasi pihak pemerintah dan para pelaku usaha rumput laut untuk merangsang peningkatan perkembangan industri rumput laut nasional.

Selain itu, sinergitas yang dilakukan oleh kedua aktor baik pemerintah dan para pelaku usaha rumput laut adalah dengan dibentuknya Asosiasi Industri Rumput Laut Indonesia (ASTRULI) pada tanggal 28 Februari 2014, yang tujuan pembentukan ASTRULI adalah untuk mengakomodir seluruh aktivitas yang terkait dengan industri rumput laut nasional sebagai langkah awal Pemerintah Indonesia dalam melakukan sinergi dengan para pelaku usaha rumput laut. Selain itu, salah satu upaya yang dilakukan dalam sinergisasi kerjasama di antara kedua belah pihak adalah dengan melakukan sosialisasi oleh pihak pemerintah (government actor) kepada para 
pelaku usaha rumput laut dalam Musyawarah Nasional Asosiasi Rumput Laut Indonesia (ARLI) III yang dilaksanakan pada tanggal 08 Oktober 2014, di Makassar. Sosialisasi tersebut sebagai langkah upaya pemerintah dalam melakukan sinergitas dengan para pelaku usaha rumput laut yang kemudian ditanggapi dengan pemberian beberapa masukan oleh para pelaku usaha rumput laut kepada pemerintah salah satunya adalah dengan keinginan para pelaku usaha rumput laut untuk bisa mendapatkan Road Map industrialisasi rumput laut nasional (Asosiasi Rumput Laut Indonesia, 2014).

\section{c. Sinergitas dalam Upaya Standarisasi Rumput Laut Nasional}

Upaya Pemerintah Indonesia dalam melakukan sinergitas kerjasama untuk penerapan standarisasi produk rumput laut nasional bertujuan untuk menjaga nilai mutu dan kualitas produk rumput laut sehingga memiliki daya saing yang tinggi di pasar global. Strategi pertama yang dilakukan oleh Pemerintah Indonesia adalah dengan melakukan sosialisasi secara penuh kepada para pelaku usaha rumput laut, salah satunya dengan memanfaatkan Musyawarah Nasional Asosiasi Rumput Laut Indonesia (ARLI) III di Makassar, pada tanggal 08 Oktober 2014. Dalam acara tersebut terdapat para pelaku usaha rumput laut domestik yang berasal dari seluruh Indonesia sehingga sosialisasi tersebut dapat dimaksimalkan untuk dapat memberikan beberapa informasi sehingga dapat memberikan pengaruh dalam meningkatkan kualitas mutu dan hasil produksi rumput laut nasional yang salah satunya adalah untuk menunjang rantai pengembangan sektor hulu dan hilir rumput laut nasional. Dengan melakukan penerapan standarisasi pada sektor hasil budidaya rumput laut maka secara langsung akan memberikan dampak positif perkembangan hasil produksi industri rumput laut karena ditunjang dengan bahan baku (raw material) rumput laut yang memiliki kualitas tinggi (Asosiasi Rumput Laut Indonesia, 2014).

Dengan membentuk PT 65-05 yaitu Panitia Teknis Perumusan SNI dengan kode 65-05 untuk produk pengolahan hasil perikanan, Pemerintah Indonesia melalui Badan Standarisasi Nasional (BSN) mengeluarkan kebijakan yang menyatakan bahwa dalam proses perumusan Standar Nasional Indonesia (SNI) khususnya terhadap produk rumput laut pemerintah meminta bantuan kepada para pelaku usaha rumput laut dalam hal ini dikoordinasi oleh Asosiasi Rumput Laut Indonesia (ARLI) 
sebagai langkah untuk melakukan kerjasama berupa bentuk sinergitas di antara kedua belah pihak baik pemerintah dan para pelaku usaha rumput laut dalam melakukan upaya bersama untuk mengharmonisasikan penerapan standarisasi sebagai langkah untuk meningkatkan daya saing produk rumput laut Indonesia di pasar global (Kementerian Kelautan dan Perikanan, 2014).

\section{d. Skema Sinergitas Rancangan Kebijakan}

Dalam revitalisasi, Pemerintah Indonesia mengeluarkan kebijakan untuk mendorong kepada para petani (pembudidaya) dengan memberikan bantuan seperti sosialisasi, transfer teknologi, akses informasi, dan bantuan berupa dana untuk merangsang para pembudidaya agar dapat mengoptimalisasi usaha dalam meningkatkan mutu dan kualitas hasil produksi. Demikian halnya dengan industrialisasi, Pemerintah Indonesia melalui beberapa Undang-Undang serta kebijakan yang dikeluarkan secara penuh memberikan dorongan dan dukungan kepada para pelaku usaha untuk dapat meningkatkan pertumbuhan industri pengolah rumput laut. Kebijakan yang diterapkan oleh Pemerintah Indonesia dalam upaya peningkatan daya saing produk rumput laut di pasar global tergolong ke dalam The Role of Support Policies karena bentuk strategi kebijakan yang diterapkan oleh Pemerintah Indonesia bersifat kebijakan domestik dengan memberikan penekanan terhadap peningkatan sektor hulu dan hilir melalui kebijakan secara langsung dalam memberikan bantuan atau dukungan kepada para pelaku usaha dalam mengoptimalisasi implementasi kebijakan.

Adapun strategi kebijakan yang diterapkan oleh Pemerintah Indonesia dalam upaya peningkatan daya saing produk rumput laut di pasar global adalah dengan melakukan sinergitas ke dalam tiga sektor kebijakan seperti revitalisasi, industrialisasi, dan standarisasi. Skema konsep kebijakan yang diajukan oleh para pelaku usaha rumput laut memiliki bentuk rancangan yang sangat jelas dan sangat optimal. Peran aktor yang sangat diperhatikan dan diberikan rancangan gambaran yang jelas terhadap masing-masing fungsi yang bertanggung jawab sehingga implementasi dapat dijalankan dengan maksimal. 


\section{Kesimpulan}

Kelautan dan perikanan merupakan salah satu sektor unggulan yang diperdagangkan di pasar global karena dipengaruhi oleh tingginya permintaan dunia sebagai bahan makanan, bahan baku makanan, farmasi, kosmetik, dan bahan olahan lainnya. Rumput laut merupakan salah satu komoditas unggulan dari sektor kelautan dan perikanan yang terus mengalami peningkatan permintaan dunia sebesar 5-10\% setiap tahunnya. Rumput laut diminati di pasar global karena kegunaan dan manfaat sebagai bahan baku industri yang dapat diolah hingga menjadi 500 jenis end product.

Indonesia merupakan salah satu negara produsen dan eksportir rumput laut terbesar di antara beberapa negara produsen rumput laut di dunia berdasarkan volume ekspor produk di dunia. Akan tetapi, sebagai eksportir rumput laut terbesar Indonesia bukan merupakan eksportir rumput laut terbesar di dunia berdasarkan nilai ekspor produk. Hal tersebut disebabkan oleh jenis produk rumput laut yang diekspor oleh Indonesia di pasar global mayoritas merupakan produk bahan mentah (raw material) sebesar $80 \%$ dan 20\% sisanya merupakan produk bahan olahan.

Menyadari besarnya potensi yang dimiliki, maka Pemerintah Indonesia mengambil langkah untuk menerapkan kebijakan peningkatan daya saing produk rumput laut Indonesia di pasar global melalui skema kebijakan revitalisasi sektor hulu, industrialisasi sektor hilir, dan penerapan standarisasi produk rumput laut melalui Standar Nasional Indonesia (SNI). Tujuan dari diberlakukannya kebijakan tersebut oleh Pemerintah Indonesia adalah untuk memberikan nilai tambah produk rumput laut Indonesia di pasar global sehingga bisa memberikan dampak positif terhadap peningkatan devisa negara dan kesejahteraan masyarakat. Melalui konsep Blue Economy, Pemerintah Indonesia menerapkan kebijakan yang bersifat dapat mengakomodir seluruh sektor kelautan dan perikanan yang dianggap potensial untuk dikembangkan sehingga dapat memacu sistem pembangunan ekonomi yang berkelanjutan (sustainable development).

\section{Daftar Rujukan}

\section{Buku dan Dokumen}

Asosiasi Rumput Laut Indonesia. (2014). Potensi Ekspor Rumput Laut Kering dan Kebijakan yang diperlukan untuk. Meningkatkan Ekspor Rumput Laut. Dokumen. 
Bank Indonesia. (2012). Produksi Budidaya Rumput Laut Dunia. Dokumen.

Bappenas. (2014). Kajian Strategi Pengelolaan Perikanan Berkelanjutan. Dokumen.

Creswell, J. W. (1994). Research Design: Qualitative and Quantitative Approaches. California. Sage Publicants.

Goldstein, A. (2008). Multinational Companies from Emerging Economies: Coposition, Conceptualization and Direction in the Global Economy. International Political Economy Series. UK. Palgrave Mcmillan.

Johnson, C. (2004). The Sorrow of Empire: Millitarism, Secrecy, and The End of Republic. UK. British Library.

Kementerian Kelautan dan Perikanan. (2012). Kebijakan Ekonomi Kelautan dengan Model Ekonomi Biru. Dokumen.

Kementerian Kelautan dan Perikanan. (2013). Kontinyuitas dan Kualitas Produlesi dalam Menunjang Masa Depan Rumput Laut Indonesia. Dokumen.

Kementerian Perindutrian. (2012). Industri Rumput Laut Indonesia. Dokumen.

Kementerian Perindustrian. (2014). Wamenperin Resmikan Asosiasi Industri Rumput Laut Indonesia (ASTRULI). Siaran Pers.

Lestari, D. P. (2013). Daya Saing Produk Hilir Rumput Laut Indonesia. Bogor. Institut Pertanian Bogor.

Lembaga Ilmu Pengetahuan Indonesia. (2009). Optimalisasi Pemanfaatan Sumber Daya Ekonomi Hayati Laut Kasus Budidaya Rumput Laut. Jakarta. LIPI Press.

Perwita, B. A A. \& Mochamad, Y. Y. (2005). Pengantar Ilmu Hubungan Internasional. Bandung. Remaja Rosdakarya.

Subarsono. (2005). Analisis Kebijakan Publik: Konsep. Teori dan Aplikasi. Yogyakarta. Penerbit Pustaka Pelajar.

Undang-Undang Republik Indonesia Nomor 45 Tahun 2009 tentang Perikanan. Dokumen.

Winarno, B. (2008). Globalisasi: peluang atau ancaman bagi Indonesia. Jakarta. Erlangga.

\section{Jurnal}

Bolesta, A. (2007). China as a Developmental State. London School of Economics and Political Science. Montenegerin Journal of Economics. No. 5

Suwitri, S. (2008). Jejaring Kebijakan dalam Perumusan Kebijakan Publik. Suatu Kajian Tentang Perumusan Kebijakan Penanggulangan Banjir dan Rob 
Pemerintah Kota Semarang. Jurnal Delegasi Jurnal Ilmu Administrasi STIA Banjarmasin. Vol. VI, No. 3, Hal. 01-32.

Winanti, P. S. (2003). Developmental State dan Tantangan dalam globalisasi. Jurnal Ilmu Sosial dan Politik. Vol. 7, No. 2.

\section{Artikel Online}

Asosiasi Rumput Laut Indonesia. (2014). "Pengusaha Rumput Laut Minta Ekspor Bebas Pungutan.” Diakses pada http://swa.co.id/swa/trends/management/pengusaha-rumput-laut-mintaekspor-bebas-pungutan

Christopher W. (2014). "Reimagining Governments”. 18 Desember 2014. Diakses pada http://www.optimumonline.ca/article.phtml?e=eeafictnb\&id $=470$.

Kementerian Kelautan dan Perikanan. (2014). "Blue Economy, Upaya Optimalisasi Sumberdaya Kelautan dan Perikanani”. Diakses pada http://www.kp3k.kkp.go.id/index.php/arsip/c/183/Blue-EconomyUpaya-Optimalisasi-Sumberdaya-Kelautan-dan-Perikanan/?category_id=21

Kementerian Kelautan dan Perikanan. (2016). "Laut Indonesia: Potensi Besar Perikanan Tangkap.” Diakses pada http://www.investasikp.co.id/laut-indonesiapotensi-besar-perikanan-tangkap/

Kementerian Kelautan dan Perikanan Republik Indonesia. (tanpa tahun). "Visi, Misi, Grand Strategy dan Sasaran Strategis KKP.” Diakses pada http://www.kkp.go.id/index.php/arsip/c/8278/VISI-MISI-TUJUAN-

DANSASARAN-STRATEGIS/?category_id $=65$ 